\title{
Isolation and Identification of Escherichia coli Serotype 0157 from Swabs of Rectal Faeces in Aceh Cattle
}

\author{
Mahdi Abrar ${ }^{1}$, Teuku Reza Ferasyi ${ }^{2}$, Amiruddin $^{3}$, Fakhrurrazi $^{1}$, Erina ${ }^{1}$, Rusli \\ Sulaiman ${ }^{3}$, Rina Aulia Barus ${ }^{4}$, Teuku Shaddiq Rosa ${ }^{5}$, Rezky Ramadhan ${ }^{5}$.
}

\begin{abstract}
${ }^{1}$ Laboratory of Microbiology, Faculty of Veterinary Medicine, Universitas Syiah Kuala, Banda Aceh, Indonesia ${ }^{2}$ Laboratory of Veterinary Public Health, Faculty of Veterinary Medicine, Universitas Syiah Kuala, Banda Aceh, Indonesia.

${ }^{3}$ Laboratory of Clinic, Faculty of Veterinary Medicine, Universitas Syiah Kuala, Banda Aceh, Indonesia.

${ }^{4}$ Cattle Breeding and Forage Centre, Directorate General of Livestock, Ministry of Agriculture of Republic of Indonesia, Aceh Besar, Aceh, Indonesia.

${ }^{5}$ Center for Tropical Veterinary Studies-One Health Collaboration Center, Universitas Syiah Kuala, Banda Aceh, Indonesia.

*Coresponding author._Emai:l teuku_rezaferasyi@unsyiah.ac.id
\end{abstract}

\begin{abstract}
Escherichia coli Serotype O157 (hereafter, E. coli O157) is known as a very important food-borne pathogen and the case spread world-wide in human. This study was aimed to isolate the bacteria of E. coli O157 from faecal sample of rectal swabs in aceh cattle. A number of 85 rectal swab samples were collected from aceh cattle in Cattle Breeding and Forage Centre of Directorate General of Livestock, Ministry of Agriculture of Republic of Indonesia, in Indrapuri of Aceh Besar District, Aceh Province. The samples were taken to the Laboratory for isolaton by culturing in eosin methylene blue agar (EMBA) medium and then performed Gram staining and indol, methyl red, voges proskauer and citrate (IMVIC) test, followed by cultured in selective medium sorbitol Mac Conkey agar (SMAC), and proven using O157 latex agglutination test to exactly confirm the E. coli serotype O157. The results of this study were analysed descriptively. A number of 5 sampels among 85 rectal swab samples of aceh cattle were found positive for E. coli O157 $(6 \%)$. Therefore, a further study is needed in aceh cattle as it could direct to the existence of zoonotic agents of E. coli $\mathrm{O} 157: \mathrm{H} 7$, which is need to control for prevention of pathogenic transmission.
\end{abstract}

Keywords: Aceh cattle, rectal swabs, E. coli. O157, zoonoses, pathogen

\section{INTRODUCTION}

Escherichia coli $\mathrm{O} 157$ (E. coli $\mathrm{O} 157$ ) is a very important food-borne pathogen and the case spread world-wide in human. In particular, this bacteria has been identified as the main cause of infection in humans in developing countries. The route of infection to human is possibly through the contamination of food by animal feces [1-4]. The bacteria will release shiga toxin that acts on kidney, intestine and other parenchymatous organs, and, in turn could cause hemorrhagic colitis and hemolytic uremic syndrome [5].

Many studies have been conducted to isolate and identify this bacteria in cattle herds, since this animal was established as the natural reservoir of $E$. coli $\mathrm{O} 157$ [5-7]. The infection in cattle is without clinical sign, but shed the bacteria intermittently [8,9]. Several epidemiological studies conducted in many countries, including in Asia, have reported a wide range of prevalence estimates ranging from $0.1 \%$ to $62 \%$ of $E$. coli $\mathrm{O} 157$ in cattle [10]. In Indonesia, in addition of the isolation of the bacteria in feces and meat of cattle, it was found also in feces and meat of sheep as well as in chicken and human feces ]10-12]. In particular, the finding of E. coli $\mathrm{O} 157$ by Suardana et al [10] in Bali cattle has convinced the hypothesis that the serotype of this bacteria could be isolated from local breed animals 
in Indonesia.

In addition to Bali cattle, several local breeds also exist in Indonesia. For example, in the Province of Aceh most of local farmers raise local breed of cattle, which called Aceh cattle. Many of them still raise cattle using traditional management farming. Although they provided the cattle with house, but the sanitation is below recommendation standard [13]. This condition may increase the risk of existence of bacteria of $E$. coli O157. However, very little information is available, if any, on the isolation of E. coli $\mathrm{O} 157$ in Aceh cattle. Therefore, the present study aims to isolate and identified of E. coli $\mathrm{O} 157$ from samples of faeces from rectal swabs in aceh cattle.

\section{MATERIAL AND METHODS}

\subsection{Study Location}

This study was conducted in Cattle Breeding and Forage Centre of Directorate General of Livestock, Ministry of Agriculture of Republic of Indonesia, in Indrapuri of Aceh Besar District, Aceh Province, Indonesia. In this location, a number of 900 aceh cattle are raised in the area of $430 \mathrm{Ha}$. Most of cattle is raising under semi-intensive system, where the animals are allowed for free grazing during the day.

\subsection{Study Design}

A total of 85 aceh cattle were used in this study, and faecal samples of all cattle were collected [10]. The collected samples were stored into microubes, skept in cool condition, and, prepared for analysis.

The samples were incubated at $37{ }^{\circ} \mathrm{C}$ for $24 \mathrm{~h}$, and then diluted in sterile distilled water containing $0.85 \%$ $\mathrm{NaCl}$. E. coli isolation was conducted by culturing the samples in eosin methylene blue agar (EMBA) medium. The colony of $E$. coli was confirmed by round-shape formedwith metallic green and black colour in the center [14]. Further, Gram staing was performed on the bacteria, followed by indol, methyl red, voges proskauer and citrate (IMVIC) analysis. For confirmation, the bacteria were cultured in selective medium sorbitol Mac Conkey agar (SMAC) and incubated for at $37^{\circ} \mathrm{C}$ for 24 h. E. coli $\mathrm{O} 157$ is indicated by clear and colourless appearance of the colony, and sorbitol negative [14].

A final step of bacteria confirmation was carried out using 0157 latex agglutination test. This test was performed through a reaction of 1 drop isolate with 1 drop of latex reagents. The positive result of E. coli is indicated by agglutination within one minute of reaction.If no agglutination is observed within one minute, indicates the absence of E. coli O157. Results cannot be interpreted if there is agglutination of both the test and control latex

\subsection{Data Analysis}

The results of this study were analysed descriptively for the isolation of E. coli O157.

\section{RESULTS AND DISCUSSION}

To best of our knowledge, this is the first study conducted to isolate E. coli O157 from rectal swabs sof aceh cattle. The results of this study indicated that all of the samples contained coliform bacteria (Figure 1). In particular, it was shown that most of isolated bacteria was $E$. coli with the proportion of $85 \%$ from total sample. The rest of the samples contained other coliforms, possibly salmonella and shigella bacteria. Around $5 \%$ of the samples was confirmed with E. coli

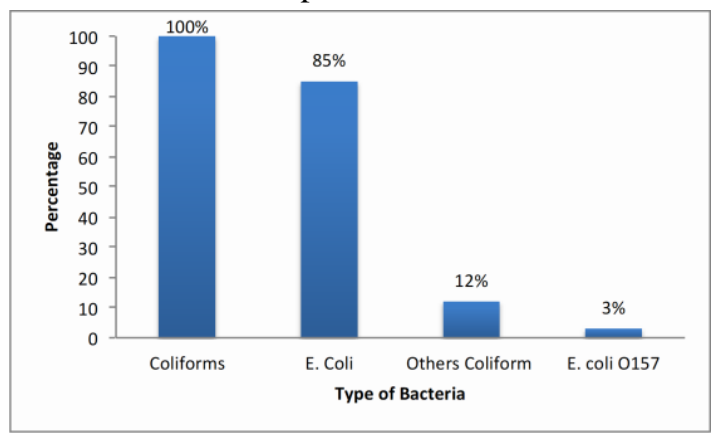

O157.

Figure 1 Composition of type of bacteria isolated from faeces of rectal swab in aceh cattle.

The results of bacteria isolation from the present study is similar to the report by Suardana et al. [15]. They were found that all faecal samples their collected from bali cattle raised in Badung Regency contained coliform. However, a lower proportion at $89.61 \%$ was reported when compared to the test on human faecal samples [16].

On the other hand, the percentage of isolation of $E$. coli in this study was higher $(85 \%)$ as compared to the results of two earlier studies above. Suardana et al. [15] was reported the proportion of $50 \%$ of E.coli isolated from total faecal samples of bali cattle. Then, in human faecal sample was only found of $15.58 \%$ from total sample [16]. In contrast, the number of samples that confirmed with E. coli $\mathrm{O} 157$ was very low in rectal faecal sample of aceh cattle (4\%) as compared to faecal sample of bali cattle (12\%) [15]. However, both of these results could give an indication of the susceptibility of local breed cattle in Indonesia to the infection by E. coli $\mathrm{O} 157$.

The confirmation of isolation of E. coli $\mathrm{O} 157$ was resulted from a serial test of Gram staining, SMAC test, latex agglutination. The initial results of SMAC test 
showed that a number of 7 samples were positive. However, after continued with latex agglutination test, it was found only 5 samples confirmed positive $E$. coli O157. The confirmation of isolation of E. coli $\mathrm{O} 157$ was based on indicator of agglutination of the test latex within one minute as a positive result, which reflected like a sand-like presipitation [11]. Figure 2 is showed an example of the results of agglutination test.

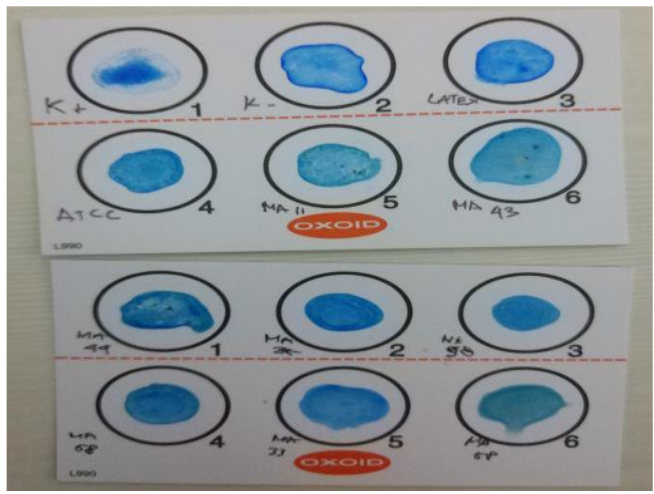

Figure 2 The results of oxoid E. coli 0157 latex agglutination test. The confirmed positive E.coli O157 was showed by the agglutination of sample of code number of MA 58.

\section{CONCLUSIONS}

Based on the results of this study, it can be concluded that E. coli $\mathrm{O} 157$ can be isolated from the faecal sample of rectal swab of aceh cattle. The existence of this bacteria showed the susceptibility of aceh cattle to E. coli $\mathrm{O} 157$ infection. Therefore, a further study is needed in aceh cattle as it could direct to the existence of zoonotic agents of E. coli O157:H7, which is need to control for prevention of pathogenic transmission.

\section{AUTHORS' CONTRIBUTIONS}

All authors equally contributed to the design, preparation, and editing of the manuscript.

\section{ACKNOWLEDGEMENTS}

The authors would like to grateful the Syiah Kuala University for supporting this study through Research Grant for Professor of 2017.

\section{REFERENCES}

[1] C.R. Dorn, Angrick EJ. Serotype O157:H7 Escherichia coli from bovine and meat sources. J Clin. Microbiol. 29 (1991)1225-1231.

[2] T.E. Besser, D.D. Hancock, L.C. Pritchett, E.M. McRae, D.H. Rice, P.I. Tarr, Duration of detection of fecal excretion of Escherichia coli O157:H7 in cattle. J. Infect. Dis. 175 (1997) 726-729.
[3] J.R. Dunn, J.E. Keen, R.A. Thompson, Prevalence of Shiga-toxigenic Escherichia coli $\mathrm{O} 157: \mathrm{H} 7$ in adult dairy cattle, J. Am. Vet. Med. Assoc. 224 (2004) 1151-1158

[4] K. Toth, T.L. Amyes, B.M. Wood, .K. Chan, J.A. Gerlt, J.P. Richard, An examination of the relationship between active site loop size and thermodynamic activation parameters for orotidine 5'-monophosphate decarboxylase from mesophilic and thermophilic organisms. Biochemistry 48(33) (2009) 80068013.

[5] Gyles CL. Shiga toxin-producing Escherichia coli: an overview. J. Anim. Sci. 2007; 85:45-62. https://doi.org/10.2527/jas.2006-508.

[6] P.A. Chapman, C.A. Siddons, D.J. Wright, P. Nor man, J. Fox, E. Crick, Cattle as a possible source of verocytotoxin-producing E. coli $\mathrm{O} 157$ infections in man, Epidemiol. Infect. 111 (1993) 439-447.

[7] V. Brusa, V. Aliverti, F. Aliverti, E.E. Ortega, J.H. de la Torre, L.H. Linares, M.E. Sanz, A.I. Etcheverria, N.L. Padola, L. Galli, P.P. Garcia, J. Copes, G.A. Leotta, Shiga-toxin producing Escherichia coli in beef retail markets from Argentina. Front. Cell. Infect. Microbiol 2(171) (2013).

DOI:| https://doi.org/10.3389/fcimb.2012.00171

[8] R.O. Elder, J.E. Keen, G.R. Siragusa, G.A. Barko cyGallagher, M. Koohmaraie, W.W. LaegredCorr elation of enterohemorrhagic Escherichia coli $\mathrm{O} 157$ prevalence in feces hides and carcasses of beef cattle during processing. Proc. Natl. Acad. Sci. 97 (2000) 2999-3003.

[9] I. Nastasijevic, R. Mitrovic, S. Buncic, Occurrence of Escherichia coli $\mathrm{O} 157$ on hides of slaughtered cattle. Lett. Appl. Microbiol. 46(1) (2008) 126131.

[10] I.W. Suardana, W.T. Artama, W Asmara, B,S, Daryono, Identifikasi Escherichia coli O157:H7 serta deteksi gen Shiga Like Toxin 1 dan 2 asal feses hewan, daging, dan feses manusia. J. Vet. 11(4) (2010) 264-270.

[11]I.W. Suardana, I.H. Utama, M.H. Wibowo, Identifikasi Escherichia coli O157:H7 dari feses ayam dan uji profil hemolisisnya pada media agar darah. Jurnal Kedokteran Hewan 8(1) (2014) 1-5.

[12] B. Sumiarto, Tingkat Infeksi dan kontaminasi bakteri Escherichia coli O157:H7 pada daging domba di Rumah Potong Hewan Yogyakarta. J. Vet. 5(3) (2004) 85-90.

[13] M.A.N. Abdullah, R.R. Noor, E. Hendiwirawan, Identifikasi penanda genetik daerah D-loop pada sapi Aceh. J. Indones. Trop. Anim. Agric. 33(1) (2008) 1-10. 
[14] E.Y.Bridson, The Oxoid Manual, 9th Edition. Oxoid Limited, England, 2006.

[15] I.W. Suardana, P.J.R.A. Putri, I.N.K. Besung. Isolasi dan identifikasi Escherichia coli O157:H7 pada feses sapi di Kecamatan Petang, Kabupaten Badung, Bali, Buletin Veteriner Udayana 8 (1) (2016) 30-35.

[16] I.W. Suardana, B. Ratnawati, Sumiarto, D.W. Lukman, Deteksi keterkaitan keberadaan coliform, E. coli, dengan keberadaan agen zoonosis E. coli O157 dan E. coli O157:H7 pada feses manusia di Kabupaten Badung Provinsi Bali. Medicina 39(3) (2008) 216-218. 